\title{
Toward love and sex narrative generation using a noun conceptual dictionary
}

\author{
Jumpei Ono ${ }^{\mathrm{a}, *}$, Miku Kawai ${ }^{\mathrm{b}}$ and Takashi Ogata ${ }^{\mathrm{c}}$ \\ ${ }^{\text {a }}$ Faculty of Software and Information Technology, Aomori University, Tokyo, Japan \\ ${ }^{\mathrm{b}}$ Faculty of Liberal Arts, The Open University of Japan, Japan \\ ${ }^{\mathrm{c}}$ Faculty of Software and Information Science, Iwate Prefectural University, Iwate, Japan
}

\begin{abstract}
At "The International Congress on Love \& Sex with Robots," love and sex issues related to robots have been discussed. This discussion of robots has applications in nursing care and other. Love and sex are also important themes for narratives. We develop a system to generate stories, and consider a robot that tells stories as one of the applications of story generation. The purpose is to present a prototyping system that generates a new narrative expression based on the theme of "love and sex" by exchanging the concept of character in the input narrative expression with a new concept using our noun concept dictionary. We call the method of collecting nouns based on a certain theme and embedding them in a story to give the story a certain atmosphere "colouring." This paper is to develop a prototype of a system that uses "colouring" to give a certain atmosphere to a story. We create a prototype and study the issues of the system. In the future, this prototype will serve as a stepping stone to a system that generates narratives based on specific themes. Eventually, we will study the use of robotic interactive psychotherapy, in which the robot converses with humans.
\end{abstract}

Keywords: Colouring, conceptual dictionary, narrative generation, noun concept

\section{INTRODUCTION}

The concept of love and sex with robots has been studied at the International Congress on Love \& Sex with Robots, organized by Levy (2009), a chess player and author of a book on AI. For example, Bendel (2020) examined the potential applications of sex robots in under-researched areas such as the military, science, and the arts, and discussed sex robots in mythology and literature, and love and sex are important themes in stories and narratives. We have been studying narrative generation and have incorporate the issues concerning love and sex with robots (Ono et al., 2020).

In this study, we do not discuss topics related to gender (Kato, 2017) (social sex differences) in the humanities and social sciences, or the nature of gender. Of course, gender is a major topic of discussion in many parts of the world. In recent years, there have been attempts to consider this topic in entertainment. For example, in foreign games, players can choose the same surname as their spouse, for the main character as their avatar (Headliner, developed by Unbound Creations, released in 2017). Other game provides the ability to attach male genitalia to biological females (Cyberpunk 2077, developed by CD Projekt RED, released in 2020). In Section 3.1.1, this study mentions, "men do not get pregnant"; however, the decision is based on the majority perception in early 2021 (in reality, there are men who have gotten pregnant (Kato, 2017), which is highly debatable, but not the subject here). We leave the above discussion for future work. This study takes a relatively narrow view of sex and love, treating sex as "sexual desire, feelings related to that desire, and actions and phenomena

\footnotetext{
${ }^{*}$ Corresponding author. E-mail: j.ono@ aomori-u.ac.jp. 2589-9953 @ 2022 - The authors. Published by IOS Press. This is an Open Access article distributed under the terms of the Creative Commons Attribution-NonCommercial License (CC BY-NC 4.0).
} 
associated with those feelings," and love as "feelings that are attracted to an object, including the self, and actions and phenomena associated with those feelings," including attachment.

Shimada (2009) proposed the following method of interspersing a story with words related to a certain word to give a certain atmosphere to the story:

For example, if you want to give a story a damp, watery feel, try placing water-related details everywhere. The story takes place on a riverbank or in a house by the sea. It's raining all the time, and the main character hears the sound of water dripping down the sink from a loose faucet. The metaphors used in the story are all related to water. If you consistently use water-related descriptions and metaphors from the beginning to the end of a story, the image of dripping water will stay in the reader's mind, independent of the story's development.

We term this method described by Shimada (2009), "colouring." In this case, "colouring" is a technique used when editing elements of a story such that a certain atmosphere is felt throughout the story, while maintaining the story's structure. In this paper, we examine the colouring of terms related to love and sex. The purpose of this paper is to present a prototype of a system that generates a new narrative expression. The prototype does this by exchanging the concepts of person, object, and place in the input narrative expression with new concepts using our noun concept dictionary (Ogata, 2015) on the theme of love and sex. This prototype is a stepping-stone toward a system that can generate stories based on specific themes.

We will study robots talking to humans, using robot-based interactive psychotherapy. Section 2 describes the proposed system, Section 3 describes the results and their evaluation, Section 4 discusses the prospects, and Section 5 concludes this paper.

\section{PROPOSED SYSTEM}

The proposed system outputs stories about love and sex. Section 2 describes the structure and algorithm of this system.

\subsection{System structure}

First, the story is input into the system. A story consists of surface textual representation and a conceptual structure. The conceptual structure has a so-called "structure tree" that represents the story content and a list of instances. The structure tree is a hierarchical structure of events in the story. An instance is a concrete object that exists in the real world. In this work, instances include characters, objects, and locations that appear in a story. Additionally, the attributes given to an instance by colouring are also considered instances themselves, assuming that they are unique information in a story. Section 2.3 provides the structure tree and the details of the list of instances.

The output of the system is a coloured story. We believe that the system can give the story an atmosphere of love and sex by sprinkling in noun concepts related to the two concepts. This assumption is based on the saying, "If you want to give a story a damp, watery feel, try placing water-related details everywhere," initially stated by Shimada (2009).

Here, the system colours the story with love and sex by transforming the initial story. This transformation of the story replaces the values of the attribute frames of the instances in the story; this adds 
explanatory events to the story's conceptual structure and changes the sentence expressions accordingly. An attribute frame is a structure that indicates the characteristics and state of an instance in a story.

The prototype of the system consists of a colouring module, a sentence generation module, a conceptual dictionary, an attribute information knowledge base, and a notation dictionary. Figure 1 presents the relationship of each mechanism.

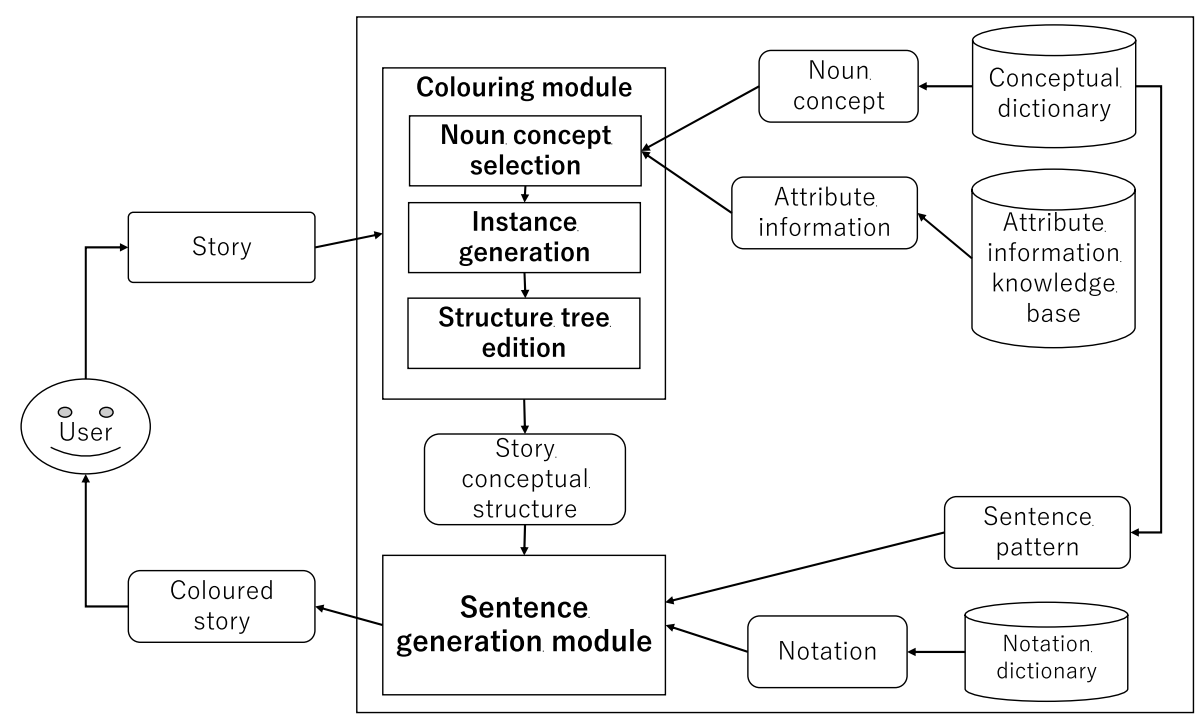

Fig. 1. Architecture of the proposed system.

- Modules

- Colouring module: This module accepts input from outside the system (limited to users in this study) and edits the structure of the story by providing noun concepts related to love and sex to the attribute frame of the target instance. The details of Noun concept selection, instance generation, and structure tree edition are described in Section 3.1. They show the colouring procedure, which involves selecting a noun concept for love and sex, creating instances based on the selected the noun concept, and editing the conceptual structure of the story based on the created instance.

- Sentence generation module: This module generates sentence expressions based on the results of the colouring module. To the sentence generation mechanism of our integrated narrative generation system (Ogata, 2020), we added the function to generate sentences based on the structure added by colouring.

- Knowledge bases and dictionaries

- Conceptual dictionary: A dictionary (Ogata, 2015) that systematically stores noun and verb concepts. Specifically, we use a noun conceptual dictionary that contains Noun concepts selected by the proposed system. The details are described in Section 2.2. Additionally, the verb conceptual dictionary contains Sentence patterns that are necessary to generate the sentence expressions of events. Sentence patterns are described in Section 3.2.

- Attribute information knowledge base: Attribute information is the knowledge that describes the dictionary definition of a concept and is stored in texts obtained from the Web dictionary (Kotobank: https://kotobank.jp/). The details are described in Section 3.1.2. 
- Notation dictionary: Notation is the expression of noun and verb concepts necessary for sentence generation. The dictionary that stores notations. The details are in Section 3.2.

\subsection{Noun conceptual dictionary}

While this section only describes the noun conceptual dictionary, Section 3.2 describes the verb conceptual dictionary only for the sentence patterns used in this study. A noun concept describes information about the meaning of a word, and the dictionary systematically stores about 12,000 noun concepts. The systematic structure is based on 5,809 categories (called intermediate concepts) and 13 hierarchies. The categories and noun concepts in the noun conceptual dictionary are all in Japanese. The data used in the prototype system are also all in Japanese. For reference in this paper, we have manually added English translations to those Japanese words (the text in "( ) " is the added English translation).

Figure 2 shows the systematic structure of the noun concept dictionary. Since it is difficult to describe the entire structure here, we have included all the categories up to the fourth level and some of the categories from the fifth level onward. The black boxes indicate noun concepts that are directly associated with instances. For example, the category “愛 (love)" has the noun concepts “愛 (love)" and “純愛 (pure love).” Within “愛 (love)”, the subcategories “慈愛 (affection)” and “友愛 (friendship)” exist. Some categories have only subcategories.

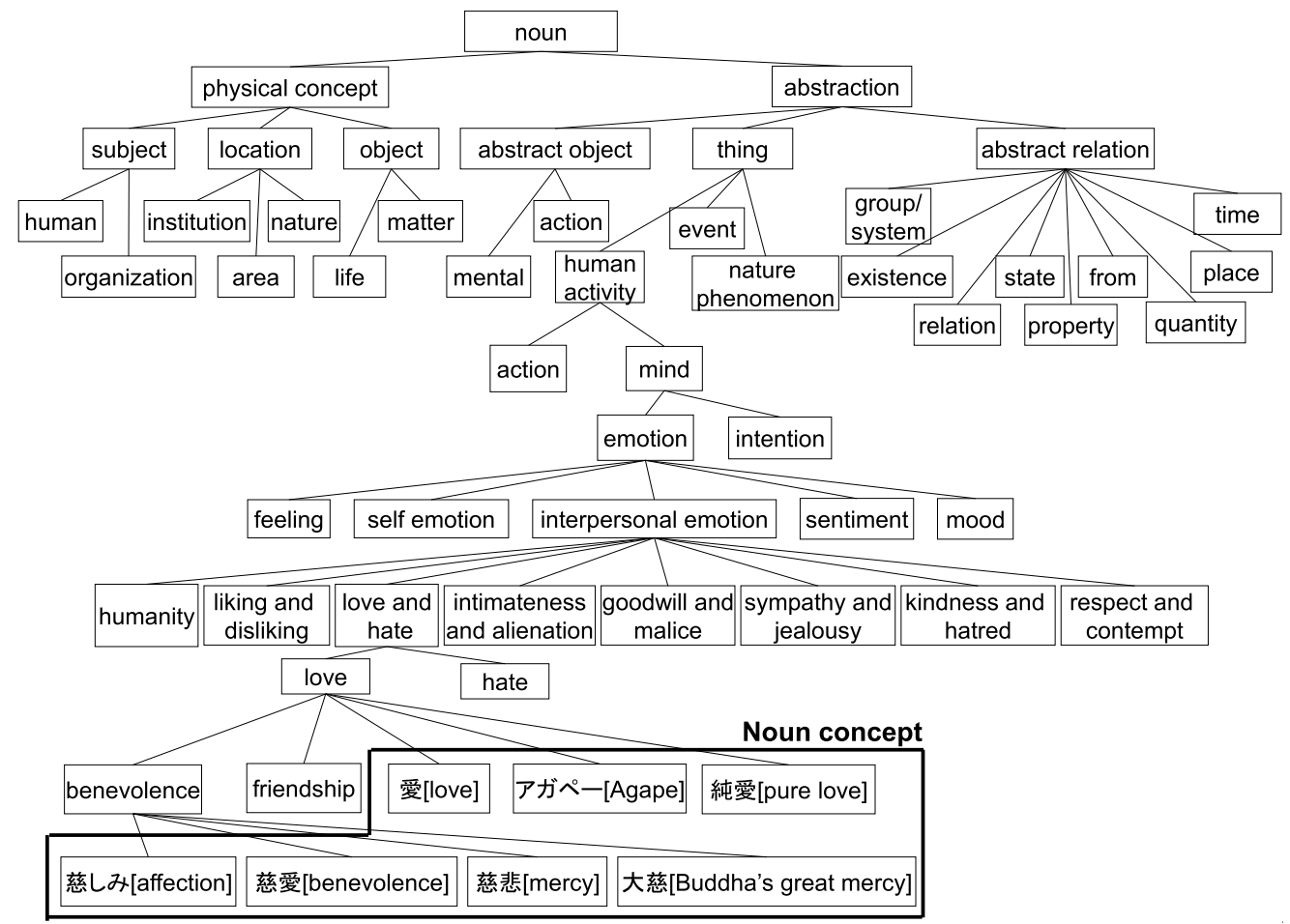

Fig. 2. Details of the noun conceptual dictionary (partially).

As this study examines noun concepts related to love and sex, we limited the scope of the noun concept dictionary that we used. Based on this study's definitions of sex and love, as described in Section 1, we used the following conditions to determine our range of noun concepts. We collected concepts 
related to love and sex from the structure of the conceptual dictionary shown in Fig. 2. Figure 3 shows the structure of the dictionary associated with the collected noun concepts. The bold boxes indicate the categories to which the collected noun concepts belong.

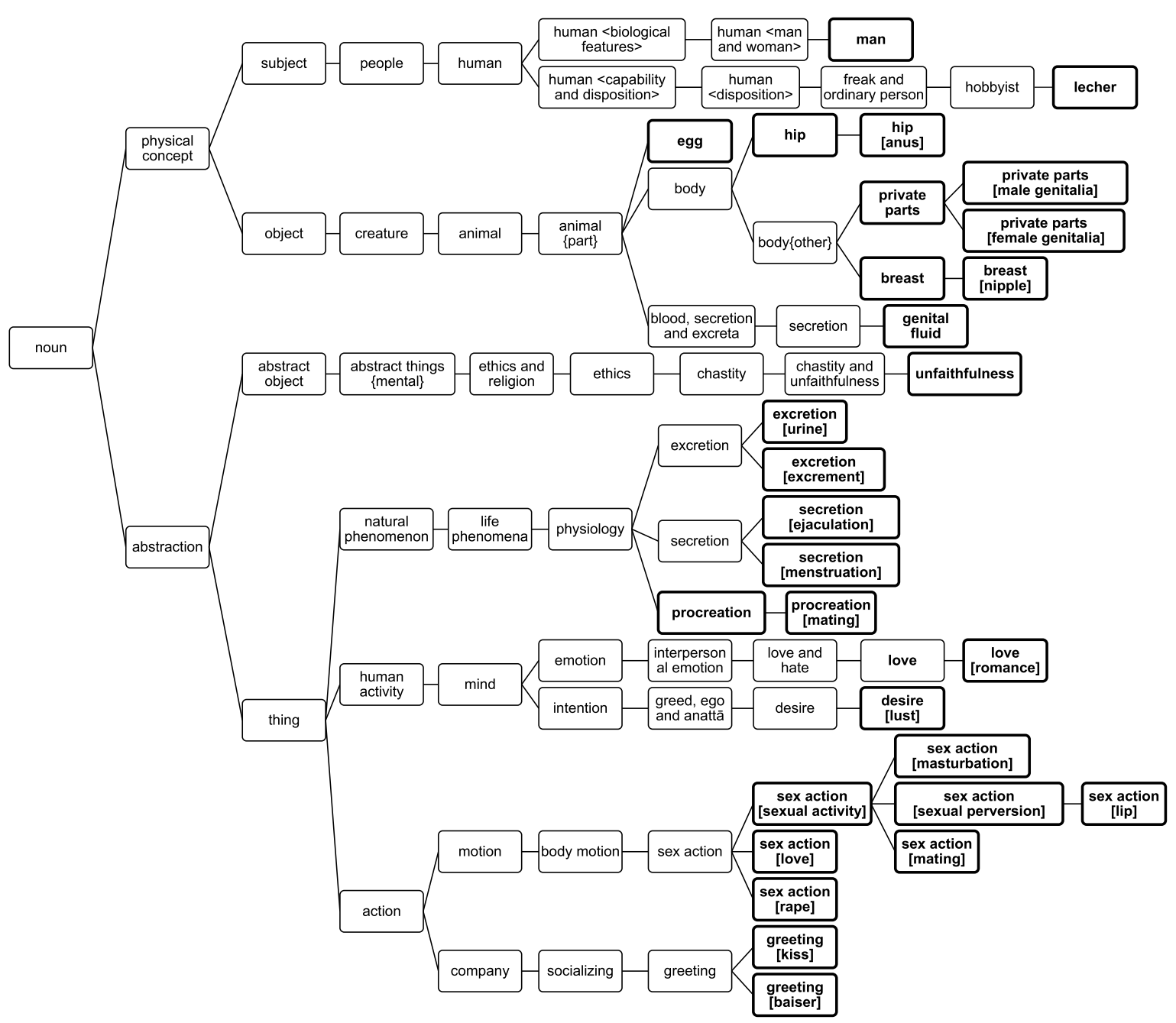

Fig. 3. Categories with collected noun concepts.

Limiting the scope using the above method allowed us to include 396 noun concepts, which were candidates for the noun concepts selected by the story colouring module. Table 1 is correspondence table between Japanese and English in Fig. 3.

We rearranged the collected noun concepts and gave them a new classification. For "emotion," "body parts," and "genital fluid," the original, or superordinate category, classification of the noun concept was used. However, "genital fluid" includes noun concepts such as “卵子 (ova)." "Tendency/temperament" has the noun concept of “好色家 (lecher).” Reproductive and excretory acts are grouped under "action," while noun concepts that are not active acts are grouped under "phenomenon." Noun concepts related to body parts are grouped into "body parts." "Sexual concepts" include “性行為 (sex act)," “欲[色欲] (desire [lust])," and “生殖 (procreation)," which summarize the abstract noun concepts contained. Each category includes the following noun concepts. 
Table 1

The correspondence of English words to Japanese words in Fig. 3

\begin{tabular}{|c|c|c|c|}
\hline English words & Japanese words & English words & Japanese words \\
\hline noun & 名詞 & natural phenomenon & 自然現象 \\
\hline physical concept & 具体 & life phenomena & 生命現象 \\
\hline subject & 主体 & physiology & 生理 \\
\hline People & 人 & excretion & 排出 \\
\hline human & 人間 & excretion [urine] & 排出[尿] \\
\hline human $<$ biological features $>$ & 人間<生物学的特徵> & excretion [excrement] & 排出[便] \\
\hline human $<$ man and woman $>$ & 人間<男女> & secretion & 分泌 \\
\hline man & 男 & secretion [ejaculation] & 分泌[射精] \\
\hline human <capability and disposition $>$ & 人間<能力・性向 $>$ & secretion [menstruation] & 分泌[生理] \\
\hline human $<$ disposition $>$ & 人間<性向> & procreation & 生殖 \\
\hline freak and ordinary person & 偏人·常人 & procreation [mating] & 生殖[交配] \\
\hline hobbyist & 趣味人 & human activity & 人間活動 \\
\hline lecher & 好色家 & mind & 精神 \\
\hline object & 具体物 & emotion & 感情 \\
\hline creature & 生物 & interpersonal emotion & 対人感情 \\
\hline animal & 動物 & love and hate & 愛増 \\
\hline animal $\{$ part $\}$ & 動物 $\{$ 部分 $\}$ & love & 愛 \\
\hline egg & 卵 & love [romance] & 愛[恋愛] \\
\hline body & 胴体 & intention & 意向 \\
\hline hip & 尻 & greed, ego and anattā & 欲·我·無我 \\
\hline hip [anus] & 尻[肚門] & desire & 欲 \\
\hline body $\{$ other $\}$ & 胴体 $\{$ その他 $\}$ & desire[lust] & 欲[色欲] \\
\hline private parts & 陰部 & action & 行為 \\
\hline private parts [male genitalia] & 陰部[男性器] & motion & 動作 \\
\hline private parts [female genitalia] & 陰部[女性器] & body motion & 全身動作 \\
\hline breast & 乳房 & sex action & 性行為 \\
\hline breast [nipple] & 乳房[乳首] & sex action [sexual activity] & 性行為[房事] \\
\hline blood, secretion, and excreta & 血·分泌物·排出物 & sex action [masturbation] & 性行為[自慰] \\
\hline secretion & 分泌物 & sex action [sexual perversion] & 性行為[性的倒錯] \\
\hline genital fluid & 生殖腺液 & sex action [lip] & 性行為[口唇] \\
\hline abstraction & 抽象 & sex action [mating] & 性行為[交尾] \\
\hline abstract object & 抽象物 & sex action [love] & 性行為[色事] \\
\hline Abstract things $\{$ mental $\}$ & 抽象物 $\{$ 精神 $\}$ & sex action [rape] & 性行為[強姦] \\
\hline ethics and religion & 倫理·宗教 & company & 交際 \\
\hline ethics & 倫理 & socializing & 社交 \\
\hline chastity & 節操 & greeting & 挨拶 \\
\hline chastity and unfaithfulness & 貞操・不貞 & greeting [kiss] & 挨拶[接吻] \\
\hline unfaithfulness & 不貞 & greeting [baiser] & 挨拶[ベーゼ] \\
\hline thing & 事 & & \\
\hline
\end{tabular}

- "Emotion": Noun concepts that means emotion

- "Phenomenon": Noun concepts that mean events that happen passively

- "Action": Noun concepts that mean action

- "Body parts": Noun concepts that mean body parts

- "Tendency/temperament": Noun concepts that mean mental tendency and temperament

- "Desire": Noun concepts that mean desire 
- "Genital fluid": Noun concepts that mean secretion with or during coitus

- "Sexual concept": Noun concepts that mean sex intercourse itself

Table 2 shows our results; there are eight classifications, and each category contains the collected noun concepts. There are many noun concepts that have similar meanings. In this paper, noun concepts with similar meanings are not collapsed together. We have tried to give as many different English translations as possible for them. For example, “岡惚れ (unrequited love)” and “片思い (one-sided love)" have almost the same meaning. But “岡惚れ (unrequited love)” is a concept that is not widely used in modern Japan. Therefore, we chose "unrequited love" as the English translation for “岡惚れ" because it is relatively rarely used ("Unrequited love" has fewer search result than "one-sided love" in the Google.).

Table 2

Categories of noun concepts related love and sex

\begin{tabular}{|c|c|}
\hline Category & Noun concept \\
\hline Emotion & 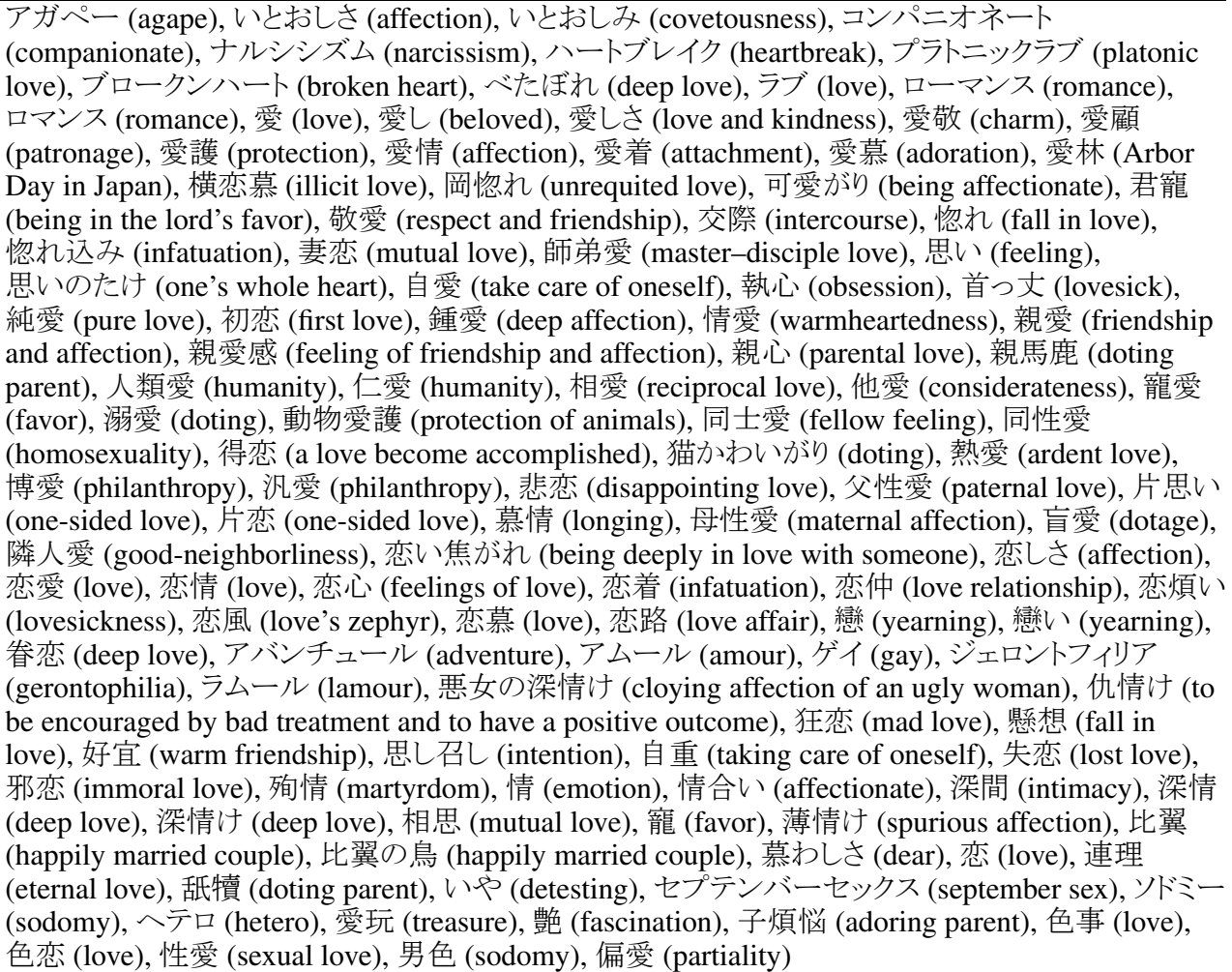 \\
\hline
\end{tabular}

Phenomenon

遺尿 (enuresis), 下だし (diarrhea), 快便 (good evacuation), 混血 (mixed race), 渋り (tenesmus), 身持ち (pregnancy), 身重 (pregnancy), 垂れ (diarrhea), 垂れ流し (diarrhea), 秘結 (constipation), 便通 (bowel movement), 便秘 (constipation), メロゴニー (merogony), メンス (menses), メンゼス (menses), 懐胎 (gestation), 懐妊 (conception), 月の物 (menses), 月経 (menses), 月役 (menses), 失禁 (incontinence), 種間 (interspecies), 受精 (fertilization), 受胎 (fertilization), 受粉 (pollination), 授精 (fertilization), 初経 (menarche), 初潮 (menarche), 殖やし (fertilization), 寝小便 (bed wetting), 身篭もり (gestation), 増殖 (multiplication), 着床 (nidation), 妊夕 (pregnancy), 妊娠 (gestation), 排卵 (ovulation), 発情 (estrus), 瀵詰まり (constipation), 無性生殖 (asexual reproduction), 有性生殖 (sexual reproduction), 胚胎 (conception), 濡衣 (wet clothes), 包茎 (foreskin), 童貞 (virginity), 生殖力 (fertility) 
Table 2

(Continued)

\begin{tabular}{|c|c|}
\hline Category & Noun concept \\
\hline Action & 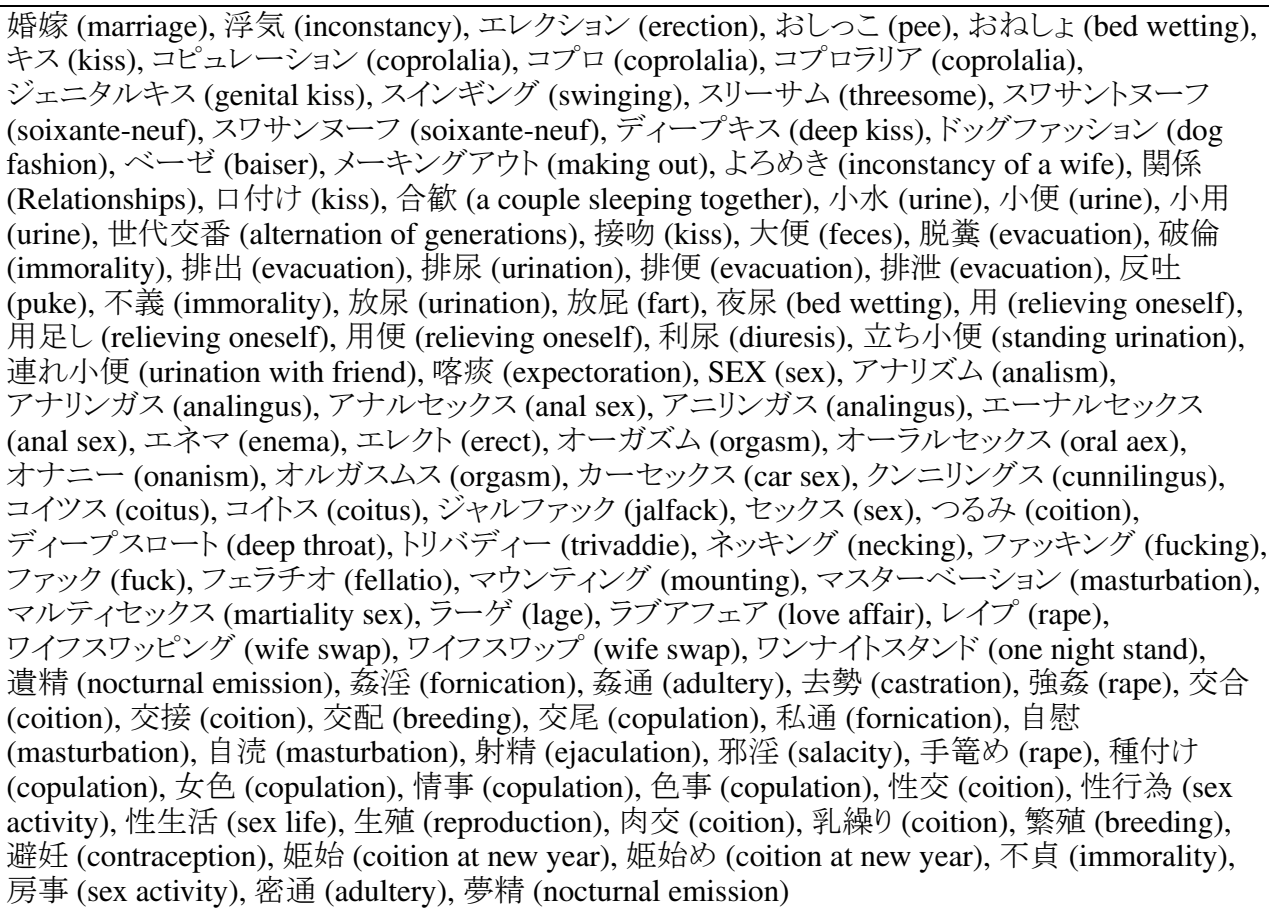 \\
\hline
\end{tabular}

Body parts ア アヌス (anus), おつぱい (breasts), グランス (glans), クリリス (clitoris), しりっぽ (hips), バスト (bust), ヒップ (hips), ペニス (penis), ヨーニ (yoni), 陰茎 (penis), 陰囊 (scrotum), 陰部 (mons veneris), 隠し所 (sexual organ), 会陰 (perineum), 蟻の門渡り (perineum), 局部 (mons veneris), 玉門 (cunnus), 穴 (anus), 腰 (waist), 差し乳 (titties), 出っ尻 (buttock), 女陰 (cunnus), 尻 (hips), 尻っぺた (hips), 恥部 (mons veneris), 乳 (breasts), 乳首 (nipples), 乳頭 (nipples), 乳房 (titties), 肛門 (anus), 臂部 (buttock)

Tendency/ ドンファン (Don Juan), 間男 (paramour), 好き者 (sensualist), 今業平 (handsome man), 純血 temperament (pureblood), 粋向き (handsome man), 粋人 (handsome man), エッチ (lecher), サディスト (sadist), サド (sadism), スキーバニー (ski bunny), スノーバニー (snow bunny), ニンフォマニア (nymphomania), フェティシズム (fetishism), ペデラスト (pederast), 艶福家 (handsome man), 漁色家 (lady killer), 好色 (amativeness), 出歯龜 (peeping tom), 初物食い (lady killer), 助平 (lecher), 女たらし (philanderer), 女好き (woman admirer), 女道楽 (woman hunting), 女郎買 (buyer of the services of a whore), 色気違い (sexual obsession), 色狂い (lecher), 色事師 (lady killer), 色女 (seductive woman), 色情狂 (erotomania), 色男 (seductive man), 色魔 (lady killer), 尻軽 (promiscuous person), 甚助 (jealous man), 精力家 (energetic man), 男たらし (coquette), 軟派 (lecher), 濡れ事師 (philanderer), 発展家 (playboy)

Desire

愛慾 (lust along with love), 情炎 (ardent lust), 情火 (lust like a fire), ウロラグニア (urolagnia), エログロ (erotic and grotesque), エロチシズム (eroticism), マゾ (masochism), 淫欲 (acolasia), 獣欲 (animal-like lust), 春情 (lust), 女出入り (trouble with women), 情痴 (love foolery), 色気 (sexiness), 色情 (lust), 色欲 (lust), 性愛 (eros), 性欲 (sexual desire), 痴情 (blind love), 肉情 (lust of the flesh), 肉欲 (lust in the flesh), 変態性欲 (paraphilia), 欲火 (lust like a fire)

Genital fluid 扸 (spermatozoa), 配偶子 (gamete), ザーメン (semen), 卵子 (ova), 腰気 (leukorrhea), 子種 (sperm), 精液 (sperm), 精子 (spermatozoa), 精虫 (spermatozoa), 白帯下 (leucorrhea), 羊水 (amniotic fluid) 


\subsection{Input and output}

Figure 4 shows that the input and output stories consist of sentences, structure trees, and instance lists. The sentence is the story that the user sees directly, and is a string representation of the content. In contrast, structure trees and instance lists are elements that represent the conceptual structure of a story. A structure tree is a tree structure representation of the events in a story, and an instance list is a collection of information on people, objects, and places among the elements that make up the events.

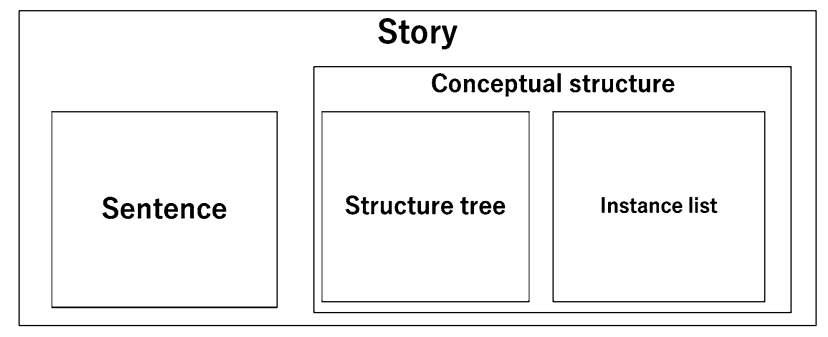

Fig. 4. Structure of a story.

Figure 5 shows the structure tree of the story. The example is: "My cousin went out to play in the flower garden. An idiot jumped out and put a knife on the windowsill. A painter named Ivan left the country." This structure tree has a terminal node. The terminal nodes are events, and the intermediate nodes represent relations between events (for more details, see (Ogata, 2020)). An event comprises a verbal concept and an "identification (ID)" that indicates an instance. The ID corresponds to the instance stored on the instance list. The ID stores a unique number that is assigned to each event in a story structure, to clearly distinguish one event from another. The "\$" sign indicates the relationship between events, "time" indicates the time when an event occurs, and "event" represents the change of state that occurs between one unit of time and the next. For this reason, time has one pair of values. The "type" indicates whether the event is an action or a description.

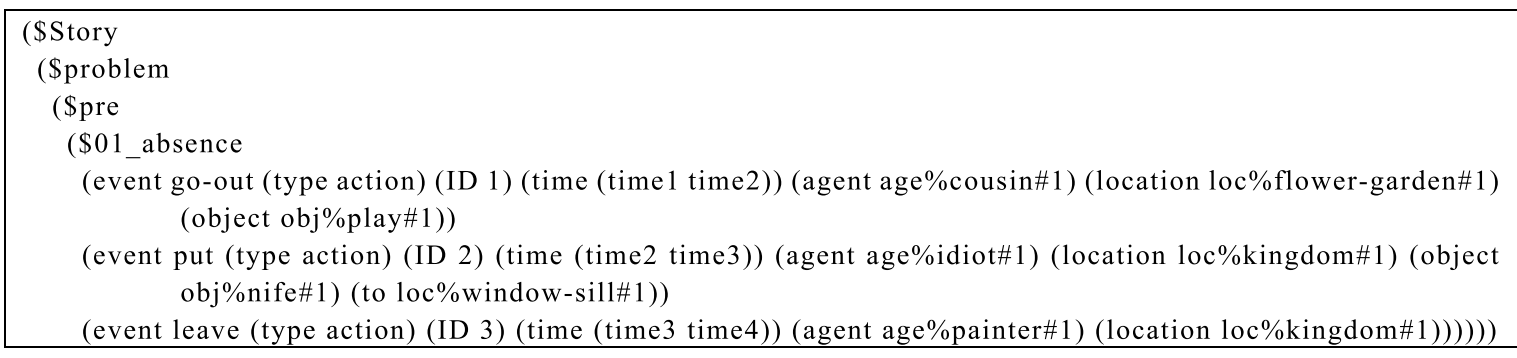

Fig. 5. Conceptual structure of a story.

Figure 6 displays the instance list, that represents characters (agent), objects, and locations included in a story. Each instance has an attribute frame, that indicates the properties, characteristics, and state of an instance. Instances are managed by unique IDs, which are prefixed with "age\%" for characters, "obj\%" for objects, and "loc\%" for locations, and a combination of concept name, "\#”, and numbers to distinguish each instance. Figure 6 shows an example that contains one instance for each character, object, and location.

An attribute frame with a unique ID for each instance. In addition to the slot for the ID, an attribute frame has one or more slots, which can either be empty or contain some value. The type of slot 
determines the value that can be inserted. "ID" is a slot to identify the instance, and a unique value is inserted for each instance. The "instance-of" is a slot to insert a noun concept, which indicates the classification of the instance. "location" indicates the location where an instance exists. In the "name" slot, the name of the instance is inserted as a string. "health" is a slot where the health or durability of an instance is expressed as a value from zero to 100 , where zero means dead or destroyed and 100 means complete. For "consciousness," if the value "awaken" is inserted, the instance is in the awakened state. For other slots, the noun concepts listed in Table 2 are inserted. For each slot, a noun concept in the category that matches the name of the slot is inserted. However, for "possession," the noun concept in the classification "genital fluid" will be inserted. For example, in the "emotion" slot, a noun concept belonging to the category "emotion" will be inserted. The slot then becomes "((ID nil) ... ((emotion 愛)).”

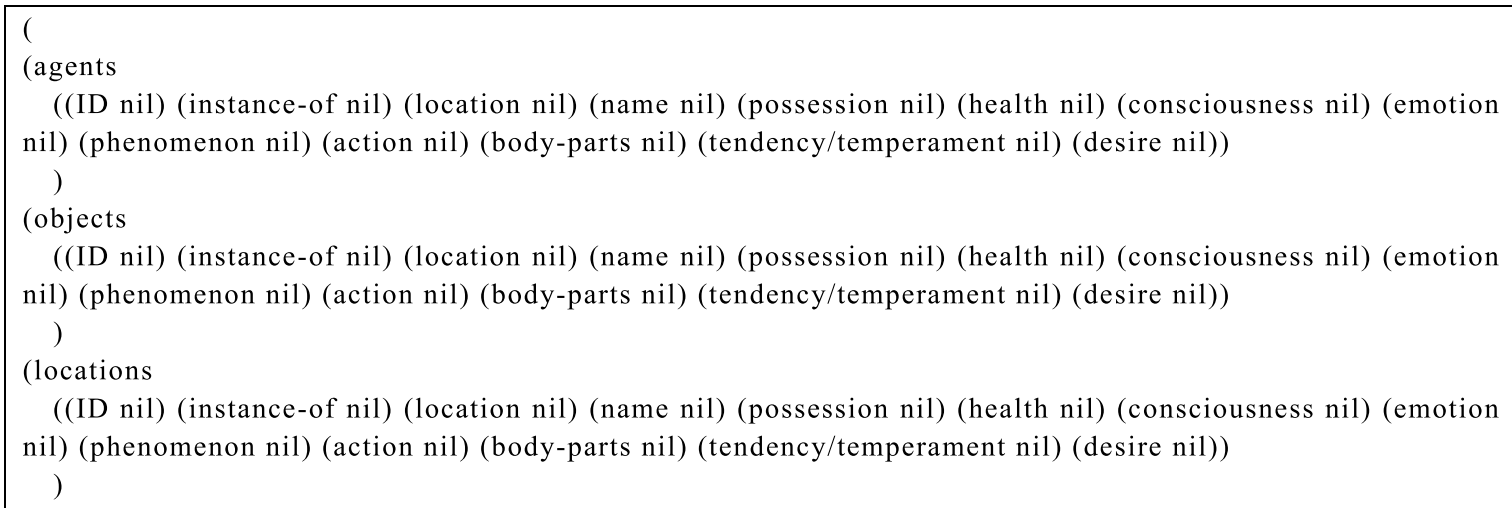

Fig. 6. Format of an instance list.

\subsection{Algorithm in proposed system}

The system assigns noun concepts related to love and sex to the person instances in the input story. The system targets the person instances in the story and rewrites the values of the attribute frames of the targets. The system selects new love- and sex-related concepts in the noun concept dictionary using co-occurrence information for all concepts in the input story. The system also inserts the selected concepts into the slots defined for each concept. The output results are converted into natural sentences. In this study, the target instances are limited to character instances.

The above algorithm consists of two steps, and the first step has three processes.

I. Editing the input instance list and structure tree by the story colouring mechanism

I-1. Selecting a noun concept for each instance and selecting attribute information associated with the noun concept.

I-2. Instance creation based on the selected noun concept and attribute information by the instance generator, and insertion of the created instance into the attribute frame of one of the existing instances.

I-3. Insertion of explanatory structure to a narrative based on an edited instance list.

II. Generation of sentence expressions based on the conceptual structure of a story by the sentence generation mechanism. 


\section{DETAIL OF ALGORITHM}

We now provide the details of the algorithm in the order in which they are described in Section 2.4.

\subsection{Colouring a story}

This section examines the central mechanism of the system. As mentioned in Section 2.1, this paper assumes that colouration can be achieved by interspersing the input stories with noun concepts related to love and sex. Therefore, the method of selecting noun concepts related to love and sex is an important part of the colouring process. The story colouring mechanism gives noun concepts related to love and sex to instances that are components of the input story. For this purpose, it performs the processes described in Section 3.1.1 and Section 3.1.2, for all the human instances in the instance list. Then, based on the results, we apply the process in Section 3.1.3 to the structure tree.

\subsubsection{Selecting noun concepts and attribute information}

This process selects the instance list and the structure tree from the input story and processes them separately. They are combined via instance IDs. As the two are distinguished by a clear symbol, different processing functions are applied to each based on that symbol.

The first step is to select a noun concept for each person instance in the instance list. This is the attribute frame of the instance. There are two possible ways to select noun concepts: one is to select noun concepts completely at random and the other is to select those concepts that have some relation to the instance being coloured. The new noun concept is selected from the range related to love and sex in the noun concept dictionary. For this, the system employs the following two methods: (1) random selection; (2) co-occurrence. Another possible method is to use a hierarchical structure of noun concepts, but since the data in this experimental system does not create a hierarchical structure, this method should be examined in a future study. The new concept is then inserted into a specific slot in the attribute frame of the target. The attribute information of the noun concept, prepared based on the Web dictionary, is then given to the new noun concept. In this experimental system, option (2), co-occurrence, was adopted.

(1) Association of noun concepts based on random numbers

Method (1) is to select one from all the noun concepts belonging to a certain category based on a random number. The classification is chosen to correspond to the slot. It can select any noun concept; however, it has no relation to the target noun concept, except in the case of an accidental selection.

(2) Association of noun concepts based on co-occurrence information

Method (2) uses co-occurrence information with the target noun concept to select new romantic and sex-related concepts for the noun concept dictionary. If there are no co-occurrence candidates, we search for co-occurrence information using other noun concepts as mediators. The co-occurrence information allows us to use concepts that appear in the same text simultaneously. This ensures consistency within a background.

For example, suppose we want to color the instance "age\%cousin\#1" whose slot "instance-of" is “従兄@男 (cousin@man).” The module first collects noun concepts related to love and sex that have co-occurrence information with 従兄@男 (cousin@man). This co-occurrence information is provided by the noun conceptual dictionary (Ogata, 2015). In the example of 従兄@男 (cousin@man), noun concepts such as “自慰 (masturbation)”, and “オナニー (onanism)" are collected. The module selects the noun concept with the highest co-occurrence information value. If there is more than one noun 
concept with the highest co-occurrence value, the module selects the first hit noun concept when collecting them.

In addition, we have defined separate constraints on the selection of noun concepts. For example, some noun concepts do not match certain types of instances, such as "male" becoming "pregnant." Of course, such a combination is interesting as a story in some cases; however, it is necessary to control such combinations. Therefore, for each target noun concept, we have prepared combinations that cannot be selected, called a constraint condition.

- Gender restriction: concepts included in the intermediate concepts of "male" and "female"

- Noun concepts with a gender restriction are selectable (or not) depending on whether the target noun concept belongs to the "male" or "female" category.

- Age restrictions: intermediate concepts "infant," "boy/girl," "young," "adult," and "old."

- Age-restricted noun concepts are selectable (or not), depending on whether the target noun concept belongs to "infant," "boy/girl," "youth," "adult," or "old person."

- Biological restriction: intermediate concepts "animal" and "plant"

- A noun concept with a biological restriction is selectable (or not), depending on whether the target noun concept belongs to the "animal" or "plant" category.

For the selected noun concept, we provide the attribute information of the noun concept from a knowledge base prepared based on a Web dictionary. We pair the selected attribute information with the target noun concept, and input to the instance generation mechanism. We then crease the attribute information using the attribute information acquisition mechanism developed by Ono \& Ogata (2017). Figure 7 shows an example of attribute information, in which the corresponding noun concept and the content of the attribute information are described in pairs.

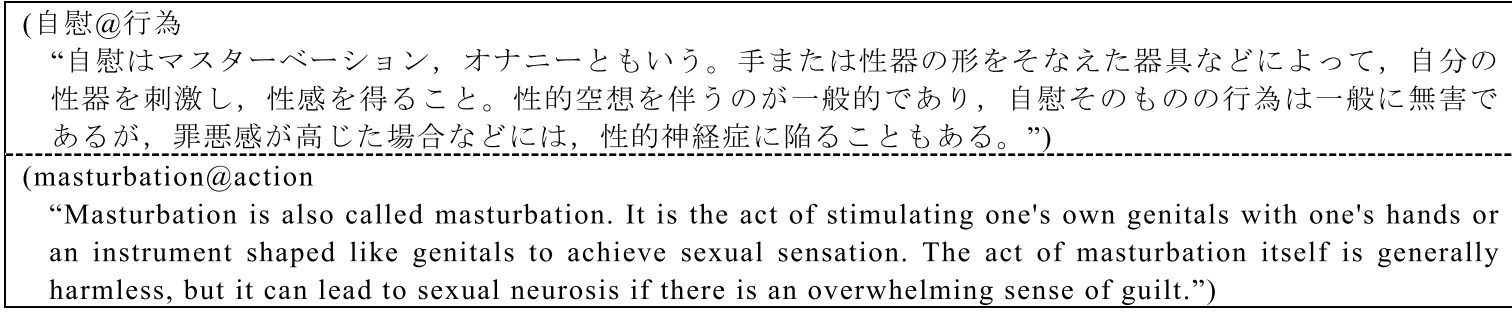

"Masturbation is also called masturbation. It is the act of stimulating one's own genitals with one's hands or an instrument shaped like genitals to achieve sexual sensation. The act of masturbation itself is generally harmless, but it can lead to sexual neurosis if there is an overwhelming sense of guilt.")

Fig. 7. Example of content of attribute information.

\subsubsection{Generating instances based on selected noun concepts and selected attribute information}

The instance generation mechanism generates an instance based on the selected noun concept and the selected attribute information. The generated instance will have the selected noun concept in the "instance-of" slot and the attribute information in the "attribute" slot, which contains the attribute information associated with the noun concept, as shown in Fig. 7 in Section 3.1.1. Figure 8 shows the attribute information of the "action" classification. Instances generated from noun concepts in the classification "emotion" are special and have a "target" slot, in which the noun concept appears. In the "target" slot, the ID of the character instance is inserted. The module randomly selects an ID of a character instance in the instance list. Figure 9 shows an example of a person instance in which a new instance is inserted. As shown in bold, the selected noun concept goes through the process described 
in this section, where an instance based on the selected noun concept is created, and information describing the selected noun concept is associated with it. This information is used in the sentence generation described in Section 3.2.

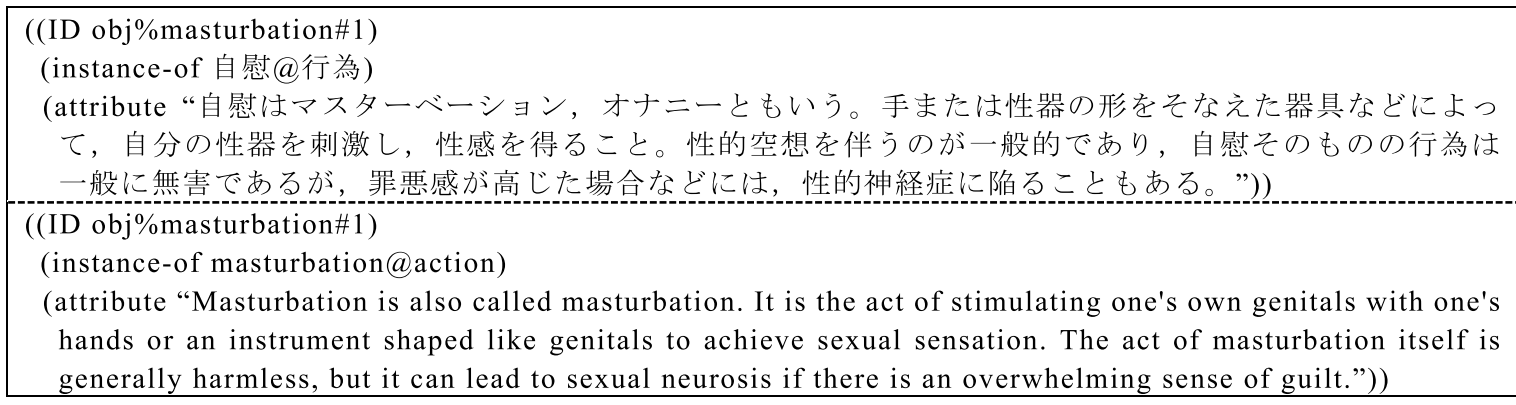

Fig. 8. Example of an instance with attribute information.

\begin{tabular}{|c|c|c|}
\hline $\begin{array}{l}((I D \text { age } \% \text { cousin \#1) } \\
\text { (instance-of cousin@man) } \\
\text { (location loc\%flower-garden\#1) } \\
\text { (name nil) } \\
\text { (possession nil) } \\
\text { (health 100) } \\
\text { (consciousness awaken) } \\
\text { (emotion nil) } \\
\text { (phenomenon nil) } \\
\text { (action masturbation) } \\
\text { (body-parts nil) } \\
\text { (tendency/temperament nil) } \\
\text { (desire nil)) }\end{array}$ & \begin{tabular}{|l}
$((I D$ age $\%$ cousin \#1) \\
(instance-of cousin@man) \\
(location loc\%flower-garden\#1) \\
(name nil) \\
(possession nil) \\
(health 100) \\
(consciousness awaken) \\
(emotion nil) \\
(phenomenon nil) \\
(action \#1[obj\%masturbation\#1) \\
(body-parts nil) \\
(tendency/temperament nil) \\
(desire nil))
\end{tabular} & $\begin{array}{l}\text { ((ID obj\%masturbation\#1) } \\
\text { (instance-of masturbation@action) } \\
\text { (attribute "Masturbation is also } \\
\text { called masturbation. It is the act of } \\
\text { stimulating one's own genitals with } \\
\text { one's hands or an instrument } \\
\text { shaped like genitals to achieve } \\
\text { sexual sensation. The act of } \\
\text { masturbation itself is generally } \\
\text { harmless, but it can lead to sexual } \\
\text { neurosis if there is an } \\
\text { overwhelming sense of guilt.") } \\
\text { ) }\end{array}$ \\
\hline
\end{tabular}

Fig. 9. Attribute frame of an instance.

\subsubsection{Inserting explanation event into structure tree based on generated instances}

The story colouring mechanism converts the generated new instances into explanatory events and inserts them into the structure tree of events in the conceptual structure of the story. The explanatory event is inserted immediately after the first appearance of each instance in the story's conceptual structure, and it describes the contents of all slots of each instance. A pair of the classification of the instance inserted in the slot $->$ attribute information of its noun concept is inserted into the conceptual structure of the story, as many slots as it has values. At the point where the explanatory event is inserted, the structure is " $<$ event $><$ value of the first slot $><$ attribute information of the value of the first slot $>\ldots<$ value of the nth slot $><$ attribute information of the value of the nth slot $>$."

Figure 10 shows an example where an explanatory event is inserted for a structure tree: "A cousin goes out to play in the flower garden." Fig. 10 shows the insertion of an explanatory event into the structure tree for "A cousin goes out to play in the flower garden.," the value of the "tendency/property" slot in the attribute frame of age\%従兄\#1 (age\%cousin\#1) and the "attribute" slot of the instance associated with that value. This explanatory event inserts into the story's conceptual structure, as many pairs of instance classification $\rightarrow$ attribute information of its noun concept inserted in the slots, as there are slots with values. This explanatory event is inserted into all explainable slots immediately after the first occurrence of an instance with that attribute frame. It does not generate explanatory events for instances that have already generated explanatory events. 


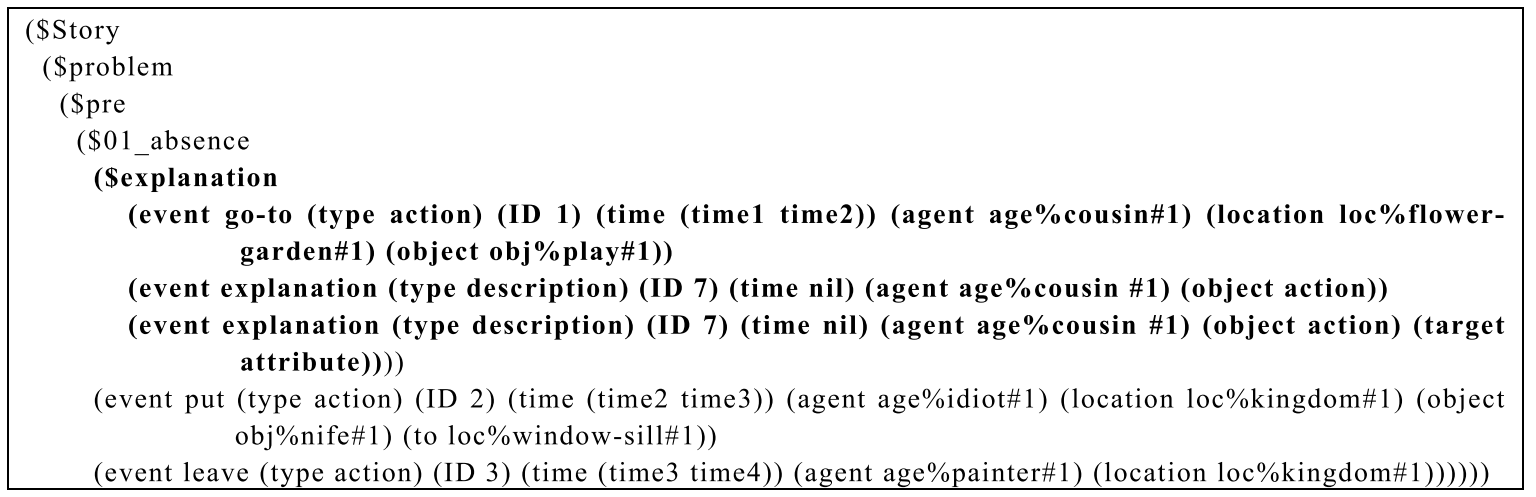

Fig. 10. Structure tree with explanation.

3.2. Editing structure tree using sentence generation module

The sentence generation mechanism inputs the conceptual structure (instance list and structure tree) of the transformed story. The sentence format of the generated sentence is determined by the target structure. The types of sentence formats correspond to (1) events, (2) slots in attribute frames, and (3) attribute information.

(1) Events generate sentences according to the sentence pattern defined for each verb concept. For example, in the event "event go-to (type action) (ID 1) (time (time1 time2)) (agent age\%cousin\#1) (location loc\%flower-garden\#1) (object obj\%play\#1)), “出かける1(go-to)" is a verb concept, and the sentence pattern is "<agent $>$ go to $<$ object $>$ in a (the) $<$ location $>$ ". " $<>$ " means the corresponding case. The generated sentence is, "A cousin goes out to play in the flower garden."

(2) For the attribute slots, a sentence pattern was determined for each slot. Table 3 summarizes the correspondence. In the table, the <agent> inserts the "instance-of" of the instance, and <object> inserts the value of the slot. In the "emotion" slot, the "instance-of" of the target instance is inserted in $<$ counter-agent $>$. The name slot, if it has a value, is inserted in the first event in the form "the <agent> named <name's slot value $>$ did $\sim$," and the name is used as the <agent $>$ thereafter.

Table 3

Sentence patterns for attribute frames

\begin{tabular}{|c|c|}
\hline Slot & Sentence pattern \\
\hline possession & <agent $>$ は<object $>$ を持つ (<agent $>$ has <object>.) \\
\hline emotion & $\begin{array}{l}<\text { agent }>\text { は<counter-agent }>\text { に<object }>\text { 感じている }(<\text { agent }>\text { feels }<\text { object }>\text { to } \\
<\text { counter-agent }>\text {. }\end{array}$ \\
\hline phenomenon & < agent $>$ は< object $>$ する $(<$ agent $><$ object $>$. $)$ \\
\hline action & < agent $>$ は< <object>する $(<$ agent $><$ object $>$. $)$ \\
\hline body parts & <agent $>$ は< <object $>$ を持つ $(<$ agent $>$ has < object $>$. $)$ \\
\hline tendency/temperament & <agent>は<object>である (<agent> is <object>.) \\
\hline desire & <agent $>$ は< <bject $>$ を持つ $(<$ agent $>$ has < object $>$. $)$ \\
\hline genital fluid & <agent $>$ は< <object $>$ を持つ $(<$ agent $>$ has < object $>$. $)$ \\
\hline sexual-concept & < <agent $>$ は< object $>$ を持つ $(<$ agent $>$ has < object $>$. $)$ \\
\hline
\end{tabular}

(3) For attribute information, all elements are used for sentence generation without omitting the hierarchical structure. The "attribute" here refers to the "attribute" slot described in Fig. 8. In other words, all the contents in the "attribute" slot are added to the sentence expression of the story.

For example, the structure in bold in Fig. 10 generates the following sentence. 
"A cousin goes out to play in the flower garden. The cousin masturbates. Masturbation is also called masturbation. It is the act of stimulating one's own genitals with one's hands or an instrument shaped like genitals to achieve sexual sensation. The act of masturbation itself is generally harmless, but it can lead to sexual neurosis if there is an overwhelming sense of guilt."

\section{RESULTS AND PROBLEMS}

We evaluated the collected noun concepts of love and sex to check the results of the colouring by our experimental system. Based on what we evaluated, we manipulated the tendency of the generated coloured stories. The evaluation method is as follows.

The evaluation criteria were values of $2,1,0,-1$, and -2 , with positive values indicating the degree of love, negative values indicating the degree of sex, and a value of zero indicating neither. Evaluators were asked to rate whether the target noun concept was a love noun concept or a sex noun concept, without specifying any specific criteria. Consequently, the mean of the values was -0.65 , slightly skewed to the negative side. Table 4 summarizes the ratings of all the noun concepts in this study.

The evaluator checked the method and criteria by judging love and sex. Words whose meanings were not immediately clear were judged after their meanings were examined. Each noun concept was evaluated as follows:

The noun concept of the emotion, which is included in descriptions containing "love" and "affection," is classified as a noun concept related to love.

Noun concepts such as "mad love" and "petting," which describe things that are generally judged to be biased or distorted in thinking, are classified as those related to sex.

Those that describe the body or physiological phenomena are classified as sex-related noun concepts.

Those that describe desire are also classified as sex-related noun concepts.

The problem with this program is that it cannot generate a variety of colourings based on love and sex from a single story. For colouring based on love and sex, we have listed three methods of noun concept selection; however, currently, only one story can be generated for each story (selection based on random numbers has multiple possibilities, but bias cannot be controlled). This is because, with the current data, there are very few candidates when selecting another noun concept based on a noun concept, and only noun concepts related to either love or sex are listed as candidates for selection. For example, for the noun concept "cousin," only noun concepts related to sex, such as "masturbation" and "sexual deviancy," are listed as candidates for selection. For example, if we restrict the choice candidates to either love or sex, we often end up with no choice candidates at all, and ultimately, we cannot colour them at all.

We now present the results of the generation without any restrictions on the noun concepts to be selected, the results of the generation with restrictions on the noun concepts to be biased toward love, and the results of the generation with restrictions on the noun concepts to be neutral. Neutral in this case means that love and sex are included to the same extent.

Figure 11 shows the results generated by the system. Figure 11 is a sex-biased story. The bold text in the figure is the sentence representation of the explanatory event inserted by the system, and the small text is the event included in the input story. The stories used for input are generated by our story grammar (Imabuchi \& Ogata, 2013) based on Propp's theory (Propp, 1968), and the noun concepts are selected based on co-occurrence information. 
Table 4

Evaluation of noun concepts

\begin{tabular}{|c|c|}
\hline Value & Evaluated noun concept \\
\hline 2 & 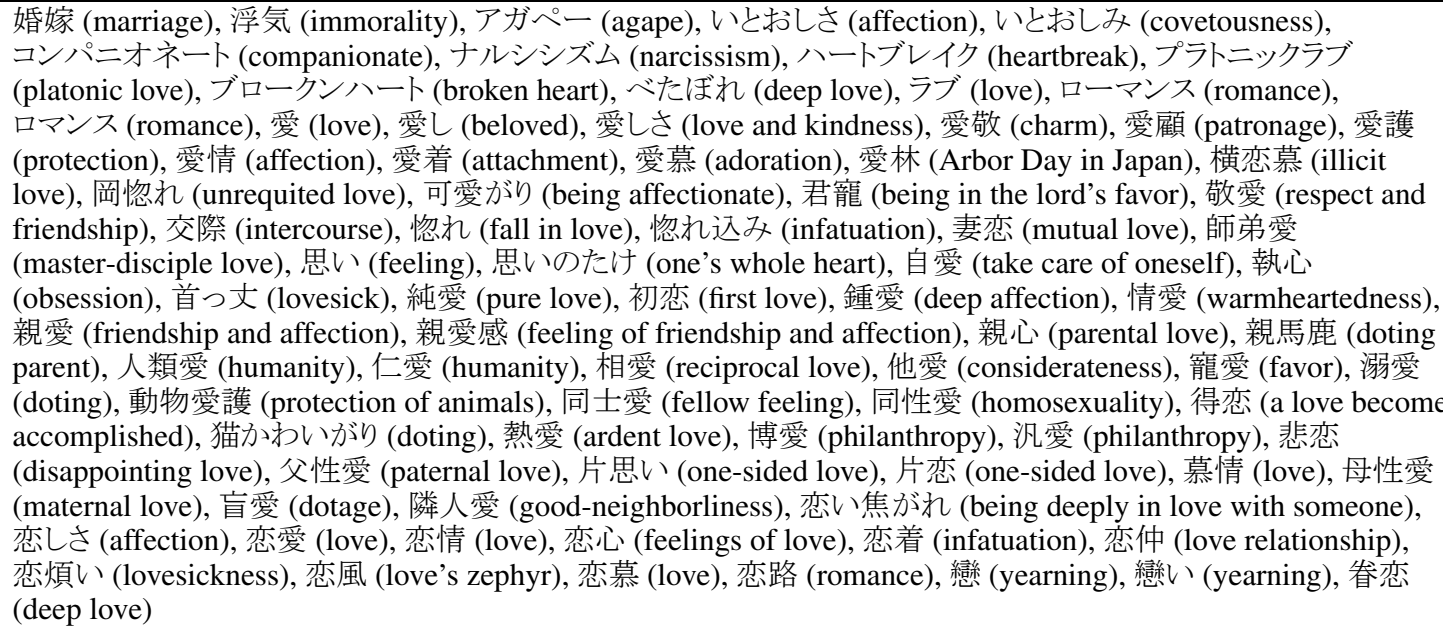 \\
\hline
\end{tabular}

エレクション (erection), おしっこ (pee), おねしょ (bed wetting), キス (kiss), コピュレーション (coprolalia), コプロラリア (coprolalia), ジェニタルキス (genital kiss), スインギング (swinging), スリーサム (threesome), スワサントヌーフ (soixante-neuf), スワサンヌーフ (soixante-neuf), ディープキス (deep kiss), ドッグファッション (dog fashion), ベーゼ (baiser), メーキングアウト (making out), よろめき (inconstancy of a wife), 関係 (Relationships), 口付け (kiss), 合歓 (a couple sleeping together), 小水 (urine), 小便 (urine), 小用 (urine), 世代交番 (alternation of generations), 接吻 (kiss), 大便 (feces), 脱粪 (evacuation), 破倫 (immorality), 排出 (evacuation), 排尿 (urination), 排便 (evacuation), 排泄 (evacuation), 反吐 (puke), 不義 (immorality), 放尿 (urination), 放屁 (fart), 夜尿 (bed wetting), 用 (relieving oneself), 用足し (relieving oneself), 用便 (relieving oneself), 利尿 (diuresis), 立ち小便 (standing urination), 連れ小便 (urination with friend), 喀痰 (expectoration), 愛慾 (lust along with love), 情炎 (ardent lust), 情火 (lust like a fire), アバンチュール (adventure), アムール (amour), ゲイ (gay), ジェロントフィリア (gerontophilia), ラムール (lamour), 悪女の深情け (cloying affection of an ugly woman), 仇情け (to be encouraged by bad treatment and to have a positive outcome), 狂恋 (mad love), 䀣想 (fall in love), 好宜 (warm friendship), 思し召し (intention), 自重 (taking care of oneself), 失恋 (lost love), 邪恋 (immoral love), 殉情 (martyrdom), 情 (emotion), 情合い (affectionate), 深間 (intimacy), 深情 (deep love), 深情け (deep love), 相思 (mutual love), 寵 (favor), 薄情け (spurious affection), 比翼 (happily married couple), 比翼の鳥 (happily married couple), 慕わしさ (dear), 恋 (love), 連理 (eternal love), 舐犢 (doting parent), 㻆 (spermatozoa), 配偶子 (gamete), 春 (sexual atmosphere), 遺尿 (enuresis), 下だし (diarrhea), 快便 (good evacuation), 混血 (mixed race), 渋り (tenesmus), 身持ち (pregnancy), 身重 (pregnancy), 垂れ (diarrhea), 垂れ流し (diarrhea), 秘結 (constipation), 便通 (bowel movement), 便秘 (constipation), ドンファン (Don Juan), 間男 (paramour), 好き者 (sensualist), 今業平 (handsome man), 純血 (pureblood), 粋向き (handsome man), 粋人 (handsome man)

Imabuchi \& Ogata (2014) conducted a preliminary experiment to compare five human-generated stories with a single story generated based on the story's grammar. They then asked 19 subjects to judge whether the author of each story was a human or a computer. About 13 subjects were able to identify the computer-generated story. However, only one of the five human-generated stories was correctly identified by more than $80 \%$ of the subjects. Additionally, Imabuchi \& Ogata (2014) asked subjects to give reasons for their decision. Using this data, they examined ways to reduce the computer-like nature of the stories. To eliminate the lack of context in the stories, they developed a technique that complements the events in Propp's theory (Propp, 1968).

Once input into the system, the story was automatically generated based on story's grammar (Imabuchi \& Ogata, 2013). The story's grammar (Imabuchi \& Ogata, 2013) is based on Propp's the- 
Table 4

(Continued)

\begin{tabular}{|c|c|}
\hline Value & Evaluated noun concept \\
\hline $\begin{array}{l}-2 \\
-2\end{array}$ & 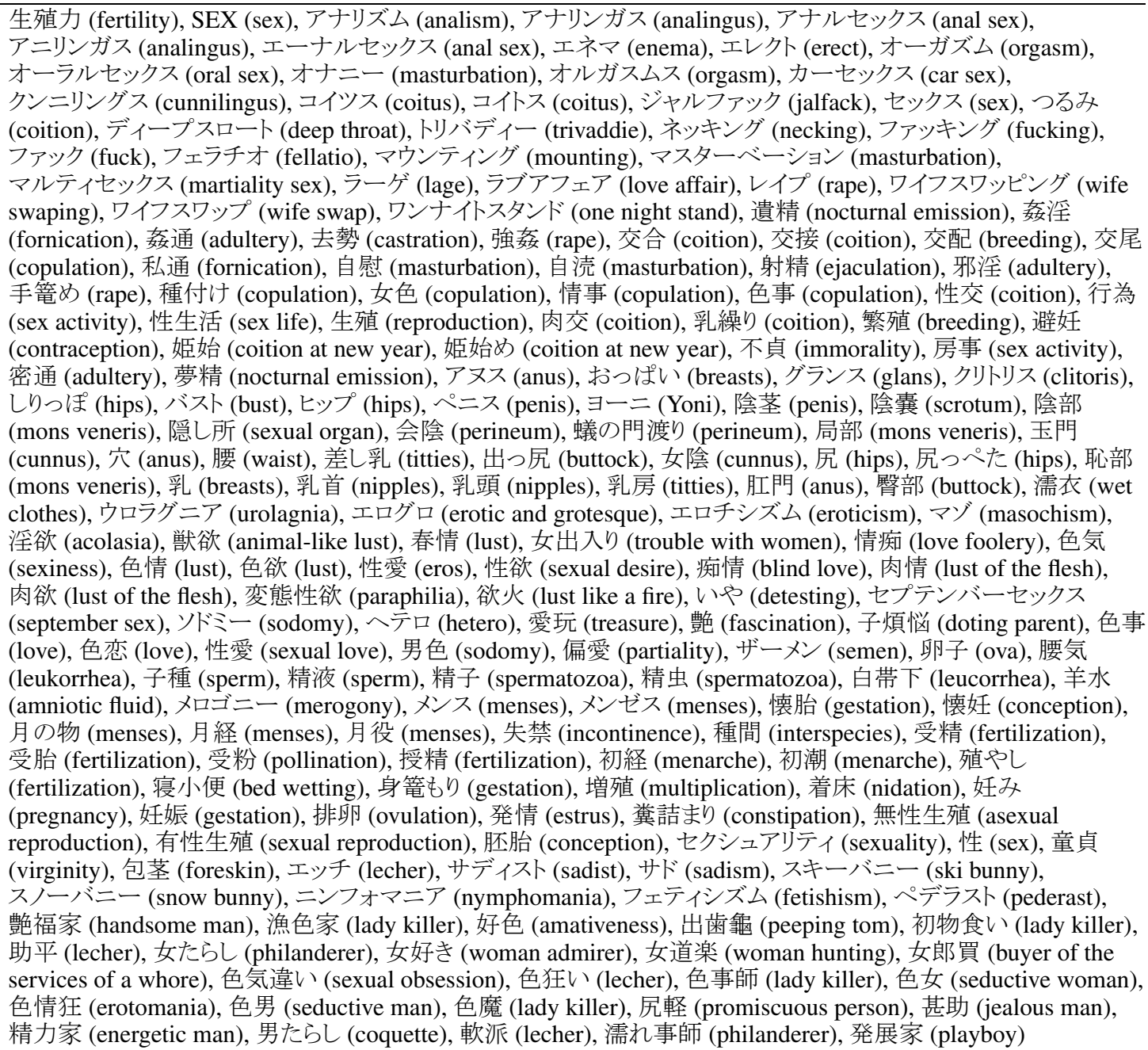 \\
\hline
\end{tabular}

ory (Propp, 1968), which can generate stories with a logical structure. However, since the generated stories contained concepts that were difficult to understand, we manually replaced them with other concepts. Specifically, within the constraints of the concept “回線 (line)," we replaced it with the noun concept “城 (castle).”

The input story based on the story grammar is as follows:

従兄が花園で遊びに出かけた。たわけ者が飛出しナイフを空ぎわに置いた。イワンといら名前 の画家が出国した。イワンが冒険をたわけ者と競争した。たわけ者が暴れた。イワンに傷が付 いた。たわけ者がイワンに競争で負けた。イワンが魔法の杖を利用した。魔法の杖が砕けた。 イワンがたわけ者から城に逃げた。メロスといら名前の男が言い張った。メロスが報酬を親王 に要求した。親王がイワンと会った。マリアといら名前の才女がイワンに会った。イワンが傷 を顔に持った。マリアがイワンで城を訪ねた。マリアが城で「イワンに傷が付く」ことを思い 出した。マリアが真実を知った。親王が城を見回った。マリアが真実をメロスに伝えた。親王 が真実を知った。親王が「メロスが親王に「マリアが老婢を助ける」ことと嘘を言う」ことに 
気付いた。メロスの競争が嘘偽りが露見した。イワンが苗代を急襲した。イワンが苗代で器官 を覚ました。イワンが宮殿に交ざった。イワンが宮殿で宮殿の中に居た。イワンが足を宮殿に 掛けた。イワンが宮殿で宮殿に住んだ。たわけ者が城に到達した。親王が城でたわけ者を射殺 した。親王がメロスを射殺した。イワンが苗代にハビコった。イワンが苗代でマリアと結婚し

た。 (My cousin went out to play in the flower garden. An idiot jumped out and put a knife on the window sill. A painter named Ivan left the country. Ivan competed with the wrongdoer for adventure. The ruffian went on a rampage. Ivan got a scar. The Trickster defeated Ivan in the competition. Ivan used his magic wand. The magic wand shattered. Ivan ran away from the ruffian to a castle. A man named Melos insisted. Melos demanded a reward from the king. The king met with Ivan. A brilliant woman named Maria met Ivan. Ivan had a scar on his face. Maria visited the castle at Ivan. Maria reminded the castle that Ivan would have a scar. Maria learned the truth. The prince looked around the circuit. Maria told the truth to Melos. The King found out the truth. The king noticed that "Melos lied to the king about Maria helping the old servant." Melos' competition was exposed as a lie. Ivan raided Miao Dai. Ivan woke up the organ in Miao. Ivan mingled in the palace. Ivan was in the palace in the palace. Ivan put his feet up in the palace. Ivan lived in the palace in the palace. The rascal reached the castle. The king shot the ruffian dead on the castle. The king shot and killed Melos. Ivan habilitated in Miao Dai. Ivan married Maria in Miao.)

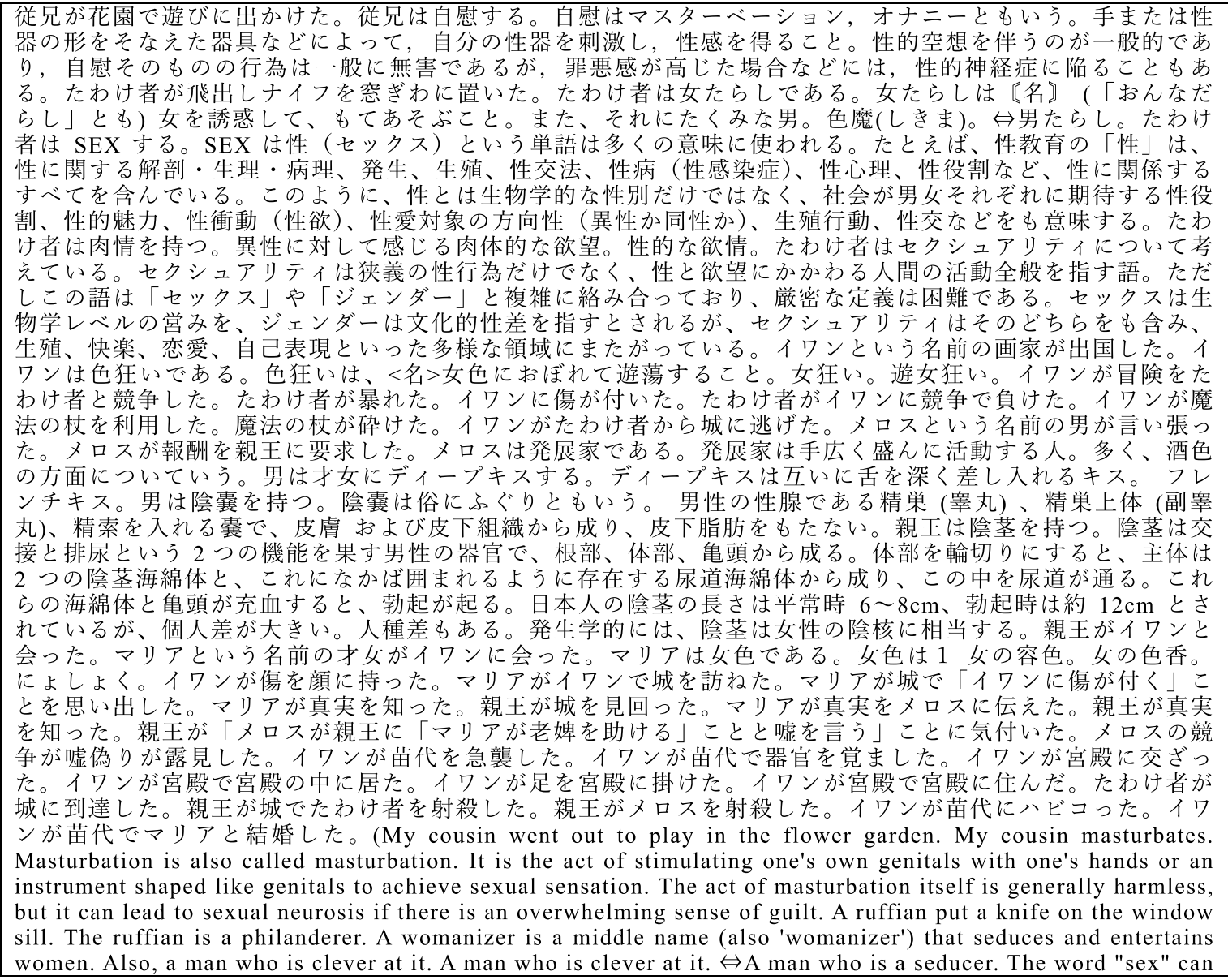

Fig. 11. Generated story (sex-related story). 
be used in many ways. For example, the word "sex" in sex education includes everything related to sex, including anatomy, physiology, pathology, development, reproduction, sexual intercourse, sexually transmitted diseases (STDs), sexual psychology, and sex roles. Thus, sex means not only biological gender, but also the gender roles expected by society for men and women, sexual attraction, sexual urge (sexual desire), sexual orientation (heterosexual or homosexual), reproductive behavior, and sexual intercourse. Many people have carnal desires. Physical desire felt for the opposite sex. Sexual lust. The sower is thinking about sexuality. Sexuality is a word that refers not only to sexual activity in the narrow sense, but to all human activities related to sex and desire. However, this term is complicatedly intertwined with "sex" and "gender," making it difficult to define strictly. Sex is said to refer to activities at the biological level, and gender to cultural gender differences, but sexuality encompasses both and spans a variety of domains, including reproduction, pleasure, love, and self-expression. A painter by the name of Ivan left the country. Ivan is a color-crazed man. Ivan is a color-crazed man. A woman crazy. A prostitute fanatic. Ivan competed with a ruffian for adventure. The ruffian went wild. Ivan was injured. The Trickster beat Ivan in a race. Ivan used his magic wand. The magic wand shattered. Ivan ran away from the ruffian to a castle. A man named Melos insisted. Melos demanded a reward from the king. Melos is a developer. A developer is active in a wide range of fields. It often refers to the area of drinking. A man kisses a talented woman deeply. A deep kiss is a kiss in which both parties insert their tongues deeply into each other. French kiss. A man has a scrotum. The scrotum is also commonly referred to as a bursa. The scrotum is a sac that contains the male sex glands: the testicles, epididymis, and spermatic cord. It is composed of skin and subcutaneous tissue and has no subcutaneous fat. The primate has a penis. The penis is a male organ that performs the dual functions of copulation and urination, and consists of a root, body, and glans. When the body is cut into a circle, the main body consists of two penile corpus cavernosum and a urethral corpus cavernosum, which is almost surrounded by the corpus cavernosum, through which the urethra passes. When these corpora cavernosa and the glans become hyperemic, an erection occurs. The length of a Japanese man's penis is said to be 6 to $8 \mathrm{~cm}$ in the normal state and about $12 \mathrm{~cm}$ when erect. There are also racial differences. Embryologically, the penis corresponds to the female genitalia. The prince met Ivan. A talented woman named Maria met Ivan. Maria is a woman of color. Female sexuality is 1 . A woman's fragrance. A woman's color. Ivan had a scar on his face. Maria visited the castle at Ivan. Maria reminded the castle that Ivan would have a scar. Maria learned the truth. The prince looked around the circuit. Maria told the truth to Melos. The King found out the truth. The king noticed that "Melos lied to the king about Maria helping the old servant". Melos' competition was exposed as a lie. Ivan raided Miao Dai. Ivan woke up the organ in Miao. Ivan mingled in the palace. Ivan was in the palace in the palace. Ivan put his feet up in the palace. Ivan lived in the palace in the palace. The rascal reached the castle. The king shot the ruffian dead on the castle. The king shot and killed Melos. Ivan habilitated in Miao Dai. Ivan married Maria in Miao.)

Fig. 11. (Continued.)

Next, Fig. 12 presents the love-biased story. The selection method of noun concepts is the same as in Fig. 11; however, the range of target noun concepts is narrowed from neutral to those evaluated as being biased toward love. Finally, Fig. 13 presents the neutral story. The selection method of noun concepts is the same as in Fig. 11, but the range of target noun concepts is narrowed to those evaluated as neutral.

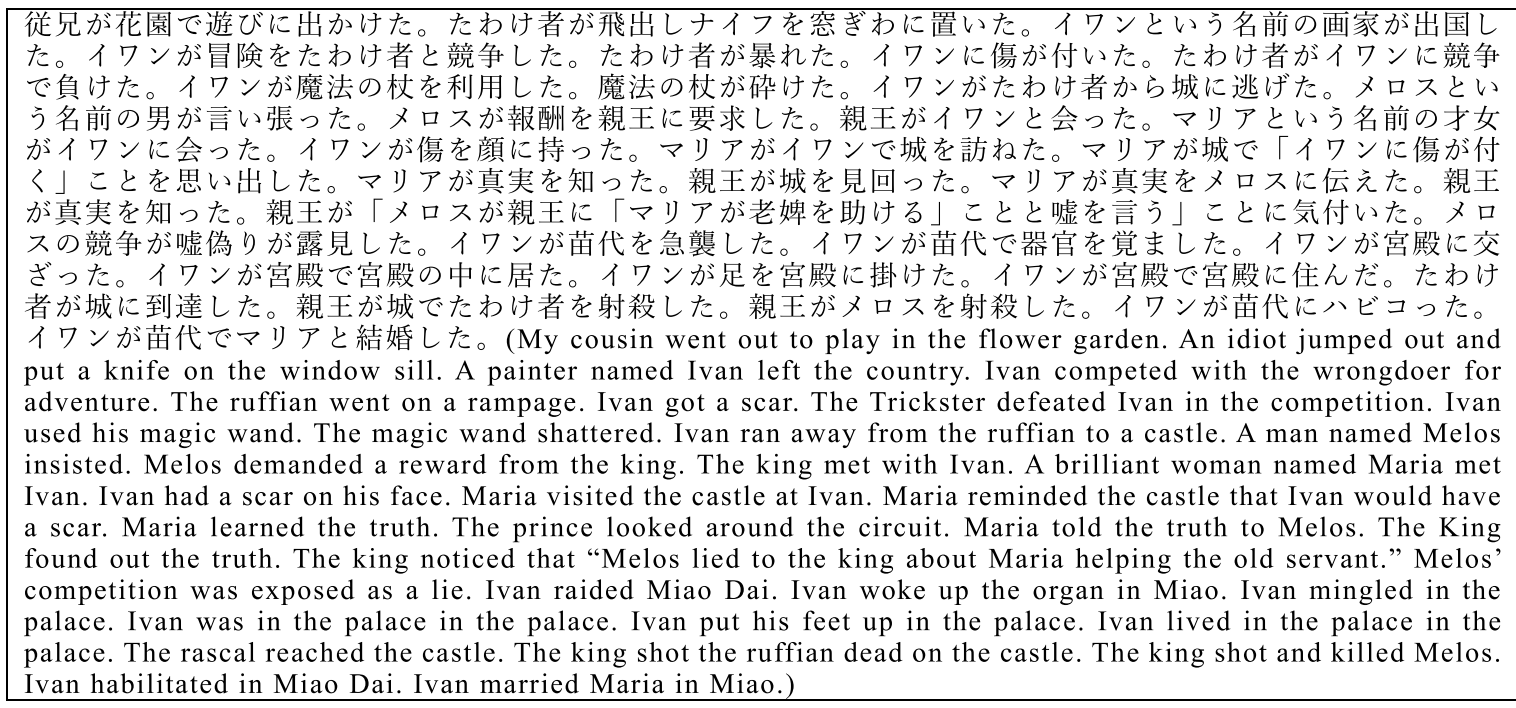

Fig. 12. Generated story (love story). 


\begin{abstract}
従兄が花園で遊びに出かけた。従兄がスワサンヌーフする。たわけ者が飛出しナイフを窓ぎわに置いた。イワ ンという名前の画家が出国した。イワンが冒険をたわけ者と競争した。たわけ者が暴れた。イワンに傷が付い た。たわけ者がイワンに競争で負けた。イワンが魔法の杖を利用した。魔法の杖が砕けた。イワンがたわけ者 から城に逃げた。メロスという名前の男が言い張った。メロスが報酬を親王に要求した。男は才女にディープ キスする。ディープキスは互いに舌を深く差し入れるキス。フレンチキス。親王がイワンと会った。マリアと いう名前の才女がイワンに会った。イワンが傷を顔に持った。マリアがイワンで城を訪ねた。マリアが城で 「イワンに傷が付く」ことを思い出した。マリアが真実を知った。親王が城を見回った。マリアが真実をメロ スに伝えた。親王が真実を知った。親王が「メロスが親王に「マリアが老婢を助ける」ことと嘘を言う」こと に気付いた。メロスの競争が嘘偽りが露見した。イワンが苗代を急襲した。イワンが苗代で器官を覚ました。 イワンが宮殿に交ざった。イワンが宮殿で宮殿の中に居た。イワンが足を宮殿に掛けた。イワンが宮殿で宮殿 に住んだ。たわけ者が城に到達した。親王が城でたわけ者を射殺した。親王がメロスを射殺した。イワンが苗 代にハビコった。イワンが苗代でマリアと結婚した。(My cousin went out to play in the flower garden. My cousin is playing swasan-nuh. An idiot jumped out and put a knife on the window sill. A painter named Ivan left the country. Ivan competed with the ruffian for adventure. The ruffian went on a rampage. Ivan got a scar. The Trickster defeated Ivan in the competition. Ivan used his magic wand. The magic wand shattered. Ivan ran away from the ruffian to a castle. A man named Melos insisted. Melos demanded a reward from the king. The man kissed the talented woman deeply. A deep kiss is a kiss in which both parties insert their tongues deeply into each other. French kiss. The king met with Ivan. A talented woman named Maria met Ivan. Ivan had a scar on his face. Maria visited the castle at Ivan. Maria reminded the castle that Ivan would have a scar. Maria learned the truth. The prince looked around the circuit. Maria told the truth to Melos. The King found out the truth. The king noticed that "Melos lied to the king about Maria helping the old servant". Melos' competition was exposed as a lie. Ivan raided Miao Dai. Ivan woke up the organ in Miao. Ivan mingled in the palace. Ivan was in the palace in the palace. Ivan put his feet up in the palace. Ivan lived in the palace in the palace. The rascal reached the castle. The king shot the ruffian dead on the castle. The king shot and killed Melos. Ivan habilitated in Miao Dai. Ivan married Maria in Miao.)
\end{abstract}

Fig. 13. Generated story (balanced story).

\title{
5. FUTURE WORKS
}

As described in Section 4, we assume that the bias in the degree of love or sex of a noun concept in the generated story determines whether it is a love story or a sex story, and we check if there is a match between the quantitative evaluation and sensory evaluation by the evaluator.

Additionally, in the future, we will collect texts that contain the noun concepts of love and sex that we have prepared from existing texts and acquire knowledge for story generation using actual examples of the noun concepts. The results of the current generation have textbook-like explanations and are worth using for educational purposes. However, to give a specific ambience to a story, we must add information that is consistent with the story. For example, 憂国 (Yūkoku, Patriotism) by Mishima (1968) or Story of the Eye by Bataille (2003) could be considered to have an atmosphere of love or sex in the story if one were to insert expressions of love or sex into the story.

The current system mainly uses the noun conceptual dictionary. The verb conceptual dictionary (Ogata, 2015) is only used for part of sentence generation. The dictionary also stores verb concepts related to love and sex. By using these verb concepts, it is possible to edit the story so that an atmosphere of love and sex can be felt from the content of the story. However, further exploration of this possibility is future work.

We also need to consider the various types of love. In the Christian concept of God's love, we use the perspective of platonic and sexual love. However, in Japan, traditionally, there is no significant distinction between sex and love. Therefore, we must consider the outcome of discussing the two concepts of love and sex in terms of their commonalities prior to discussing them separately.

\section{CONCLUSION}

This paper presents a prototyping system for generating new narrative expressions on the theme of love and sex, by giving new concepts to persons in the input narrative expressions, using our noun 
concept dictionary. To generate a story about love or sex, we extracted and classified noun concepts related to love and sex from the noun concept dictionary. To evaluate the results, we also evaluated the noun concepts. At present, we have only listed the evaluation methods and have not yet conducted the actual evaluation. Therefore, we would like to evaluate the generated stories first, and confirm whether we can evaluate the generated stories as stories about love and sex.

\section{ACKNOWLEDGEMENTS}

The research for this chapter was supported by the Japan Society for the Promotion of Science (JSPS KAKENHI), Grant No. 18K18509.

\section{REFERENCES}

Bataille, G. (2003). Medama no Hanashi [Story of the Eye]. In Madame Edwarda, Medama No Hanashi [Madame Edwarda, Story of the Eye] (Kindle Ver.), Tokyo: Kobunsha. (S. Chujo, trans.).

Bendel, O. (2020). Love dolls and sex robots in unproven and unexplored fields of application. Journal of Behavioral Robotics, 12(1), 1-12. doi:10.1515/pjbr-2021-0004.

Imabuchi, S. \& Ogata, T. (2013). A generation mechanism of macro stories based on Propp-based story grammar combined with an integrated narrative generation system. In Proceedings of the 2nd International Conference on Engineering and Applied Science (pp. 2455-2463).

Imabuchi, S. \& Ogata, T. (2014). The current development and the issues in a story generation mechanism using a whole of Propp's theory. In Proceedings of the 28th Annual Conference of the Japanese. Society for Artificial Intelligence (2F4-OS-01a-3).

Kato, S. (2017). Hajimete No Gender-Ron [Introduction to Gender and Sexuality Studies]. Tokyo: Yuhikaku.

Levy, D. (2009). Love and Sex with Robots: The Evolution of Human-Robot Relationships (English ed.) (Kindle Ver.). NY: HarperCollins e-books.

Mishima, Y. (1968). Yūkoku [Patriotism]. In Hanazakari No Mori, Yūkoku [Forest in Full Bloom, Patriotism], Tokyo: Shinchosha.

Ogata, T. (2015). Building conceptual dictionaries for an integrated narrative generation system. Journal of Robotics, Networking and Artificial Life, 1(4), 270-284. doi:10.2991/jrnal.2015.1.4.6.

Ogata, T. (2020). An integrated narrative generation system: Synthesis and expansion. In Internal and External Narrative Generation Based on Post-Narratology: Emerging Research and Opportunities (pp. 1-108). PA: IGI Global. doi:10.4018/978-1-5225-9943-2.ch001.

Ono, J., Kawai, M. \& Ogata, T. (2020). Love and sex narrative generation using narrative units and conceptual dictionaries. In Proceedings of the 5th International Congress on Love \& Sex with Robots.

Ono, J. \& Ogata, T. (2017). Attribute information acquisition in a conceptual dictionary by using Wikipedia and the use in an automatic narrative generation game. In Proceedings of the 31st Annual Conference of the Japanese Society for Artificial Intelligence (1D3-OS-29b-2in2).

Propp, V.Y. (1968). Morphology of the Folktale. (L. Scott, Trans.). Austin: University of Texas Press. Shimada, M. (2009). Shōsetsu No Sahō ABC [Manners of a Novel]. Japan, Tokyo: Sinchosha. 